\title{
Analysis and Forming of Effective System Management by Charges of Productive Enterprise
}

\author{
Shakhawat Hossain \\ Department of Mathematics, University of Barishal \\ Barishal-8200, Bangladesh
}

\author{
M.A.I. Bhuiyan \\ Department of Mathematics, University of Barishal \\ Barishal-8200, Bangladesh
}

\begin{abstract}
The aim of this research is to scrutiny of choice of an effective system management of maximization of profit and minimization of cost which are based on the use of vehicle of duality. The pedestal of the work is the analysis of cost as well as investigation on the condition of optimization of volumes and the assortment of production. The economic raising over of task is brought, the algorithm of decision and its programmatic realization are worked out. A model of optimization of production capacity and offered software product can be used in any productive enterprises.
\end{abstract}

\section{Keywords}

Effective system management, productive enterprises, maximization of yield, Cost Optimization

\section{INTRODUCTION}

Main reason of activity of expensive enterprise in market conditions maximization of income. Real market abilities of this strategic aim in all cases the productions limited to the charges that is produced. In concrete cases, an enterprise can go to the temporal decline of income and even loss. But long time to exist without an income enterprise cannot stand on competitive activity. As it is a basic terminator of income and simultaneously main factor that influences on the volume of suggestion, then making decision by guidance of enterprise without correct management charges [1]. The idea about that, how charges change depending on a production volume, very importantly for the acceptance of administrative decisions.

Therefore, the guidance must be managing the calculations of charges and profits at different production volumes for the diverse variants of actions. An enterprise can optimize a production volume and standard of prices, only comparing an income and charges that arise up at different production volumes. For the decision of this task it follows to manage charges in obedience to conception of direct cost that touches all administrative functions [2],[3]:

- an administrative account (unlike a tax and book-keeping) must be organized by dividing of charges into variables and permanent with the reflection of them after the separate articles;

- the calculation of planned and actual prime price provides for in obedience to the method of «direct cost », that for variable charges are distributed only the finished goods, and the permanent fully belong on the results of that period covered, in that they arose up;

- the analysis of charges is built on principles and indexes of marginal analysis;

- control after charges carries the simplified character and has high authenticity due to sharp reduction of items of expenses from limitation of prime price by variable charges; Assumptions on that a marginal analysis is based:
- conclusions of marginal analysis spread only to this area of relevance, that are on the that level of production, that is limited to his power;

- behavior of the combined charges and volume of output hardly certainly and arc wise within the limits of area of relevance;

- permanent charges remain independent of volume in area of relevance;

- variable charges straight proportional to the volume within the limits of relevance;

- does not change the d) cost of realization;

- prices on materials and services that is used in a production, on change;

- productivity does not change;

- are absent structural changes;

\section{METHODOLOGY}

In practice, the charges are divided into permanent and variable constituents extraordinarily difficult, but it is necessary for a management charges. There are many approaches for the decision of this task: engineer; analysis of accounts; method of peak and minimum; chart of throwing about; regressive analysis and others like that. For the exact dividing into permanent and variable constituents it follows to use mathematical methods. Coming from foregoing assumptions all approaches assume the linear model of behavior of charges that is why a relation between the combined charges and level of the productivity can be expressed by a formula

$$
\mathrm{TC}(\mathrm{Q})=\mathrm{FC}+\mathrm{AVC} \times \mathrm{Q},
$$

Where, TC - general (gross) charges at a production volume $\mathrm{Q}$ - level of the productivity

FC - permanent charges for period of producing of volume

$\mathrm{AVC}-$ variable charges are on unit of products.

A marginal analysis is based on dependence between profits from sale, by charges and income on the draught of short period, when a product of enterprise output is limited to the level of operating production capacities that are in a present tense their order. Aim of marginal analysis of to set that will take place with financial results, if the constituents of productive process will change: volume of output, expense, and price. An important operating of enterprise condition is his break-even; profits of enterprise must be not less than his charges. Mathematical interpretation of this limitation is written in a kind [4], [5], [6]:

$\mathrm{TR}(\mathrm{Q}) \geq \mathrm{TC}(\mathrm{Q})$

Where, TR - profit yield of enterprise from realization for period. 
Thus an enterprise must nurse maximizations of income from the commercial aims therefore the main criterion of making decision is:

$$
\mathrm{P}(\mathrm{Q})=\mathrm{TR}(\mathrm{Q})-\mathrm{TC}(\mathrm{Q}) \rightarrow \max ,
$$

where, $\mathrm{P}(\mathrm{Q})$ - the combined income from realization of all production volume.

TR - Total revenue,

TC - Total cost.

This information needs to the specialists of Economic Planning department and business manager at all stages of management [7]:

- on the stage of planning at making decision about prices and volumes of output on a planned period;

- on the stage of organization at entering into contracts about the sale of products and purchase of resources;

- on the stage of control at monitoring and the financial state of enterprise.

\subsection{Minimization of Charges}

There is an enterprise or firm as some organization, that carries out the charges of economic factors (such as earth, labor, capital, natural resources and others like that) for making of products that it sells to the consumers or other enterprises (to the firms), and also grant of services, in the center of theory of production. The task of rational manage that must decide an enterprise in the conditions of market or mixed economy consists in determining the amount of products and in the calculations of necessary for her producing charges of productive factors taking into account technological connections between them and prices for maximization of own incomes and sometimes producing of products at the set level of productive charges, and also minimization of charges at the set level of producing of products [8]. The task of maximization of producing of products in a long-term period looks like an enterprise:

$$
\begin{aligned}
& \mathrm{F}(\mathrm{x}) \rightarrow \max ; \\
& \mathrm{xw} \leq \mathrm{c}, \\
& \mathrm{x} \geq 0,
\end{aligned}
$$

where, $\mathrm{F}(\mathrm{x})$ - productive function;

$$
\begin{aligned}
& \mathrm{X}-\text { amount of charges; } \\
& \mathrm{W}=\left(\mathrm{w}_{\mathrm{j}}\right)^{\mathrm{j}=1, \mathrm{~m}} \text { - vector-column of costs of factors of } \\
& \text { production; } \\
& \mathrm{c}-\text { volume of productive charges. }
\end{aligned}
$$

It is a task of the concave programming according to the theory of those necessary terms of first-order of optimality of vector of charges in the terms of Lagrangian tasks [9],[10]:

$$
\mathrm{L}(\mathrm{x}, \lambda)=\mathrm{F}(\mathrm{x})+\lambda(\mathrm{c}-\mathrm{xw}),
$$

Such as:

$$
\begin{aligned}
& \frac{\partial \mathrm{L}\left(\mathrm{x}^{*}, \lambda^{*}\right)}{\partial \mathrm{x}}=\operatorname{MP}\left(\mathrm{x}^{*}\right)-\lambda^{*} \mathrm{w} \leq 0, \\
& \frac{\partial \mathrm{L}\left(\mathrm{x}^{*}, \lambda^{*}\right)}{\partial \mathrm{x}} \mathrm{x}^{*}=\left(\mathrm{MP}\left(\mathrm{x}^{*}\right)-\lambda^{*} \mathrm{w}\right) \mathrm{x}^{*}=0
\end{aligned}
$$

Where, $\lambda^{*}$ - corresponding value of multiplier of Lagrange; $\mathrm{x}^{*}$ - vector of charges.

From terms (6) (7) swims out, that for those factors of production that is used in reality:

$\operatorname{MP}_{\mathrm{j}}\left(\mathrm{x}^{*}\right)=\lambda^{*} \mathrm{w}_{\mathrm{j}}, \mathrm{j}=1, \ldots, \mathrm{m}$,
Where, $\mathrm{x}^{*}$ - an optimal vector lies on a hyper plane that answers the complete use of the set level of charges:

$$
\sum_{\mathrm{j}=1}^{\mathrm{m}} \mathrm{w}_{\mathrm{j}} \mathrm{x}_{\mathrm{j}}^{*}=\mathrm{c}, \mathrm{x}_{\mathrm{j}}^{*}>0 \text {. }
$$

The decision of the system of equalizations (8), (9) at w and $\mathrm{C}$ variables the function of demand of firm on the factors of production, a solution producing of products at the level of charges:

$$
x_{j}^{*}=\xi_{j}(w, c), j=1, \ldots, m,
$$

Determines the function from equations (8) and (9) of suggestion of products this firm:

$\mathrm{Q}(\mathrm{w}, \mathrm{c})=\mathrm{F}(\xi(\xi(\mathrm{c}))$;

$\xi(\mathrm{w}, \mathrm{c})=\left(\xi_{\mathrm{j}}(\mathrm{w}, \mathrm{c})\right)_{\mathrm{j}=1, \mathrm{~m}}$.

Multiplier of Lagrange on $\lambda^{*}(\mathrm{w}, \mathrm{c})$ maximization of producing of products related the task of enterprise to her price by correlation. Really, this fact swims out from equalization (8). Considering of maximization of producing of products task of the optimal behavior of enterprise, oriented to minimization of productive charges at the set level of suggestion (production volume) of enterprise. This task is the task of the concave programming:

$\mathrm{C}(\mathrm{x})=\mathrm{xw} \rightarrow \min$;

$\mathrm{F}(\mathrm{x})=\mathrm{q}, \mathrm{x} \geq 0$,

Where, $\mathrm{C}(\mathrm{x})$ - function of productive charges is;

$$
\mathrm{q} \text { - production volume. }
$$

Using Lagrangian of this task:

$\mathrm{L}(\mathrm{x}, \lambda)=\mathrm{xw}+\lambda(\mathrm{q}-\mathrm{F}(\mathrm{x}))$,

Have such terms of optimality of vector of charges:

$\frac{\partial \mathrm{L}\left(\mathrm{x}^{*}, \lambda^{*}\right)}{\partial \mathrm{x}_{\mathrm{j}}}=\mathrm{w}_{\mathrm{j}}-\lambda^{*} \mathrm{MP} \mathrm{P}_{\mathrm{j}}\left(\mathrm{x}^{*}\right) \geq 0, \mathrm{j}=1, \ldots, \mathrm{m}$

where, $\mathrm{MP}(\mathrm{x})$ - maximum product

$\frac{\partial \mathrm{L}\left(\mathrm{x}^{*}, \lambda^{*}\right)}{\partial \mathrm{x}} \mathrm{x}^{*}=\sum_{\mathrm{j}=1}^{\mathrm{m}}\left[\mathrm{w}_{\mathrm{j}}-\lambda^{*} \mathrm{MP} \mathrm{P}_{\mathrm{j}}\left(\mathrm{x}^{*}\right)\right]$,

$\mathrm{x}_{\mathrm{j}}^{*}=0$,

$\mathrm{F}\left(\mathrm{x}^{*}\right)=\mathrm{q}, \mathrm{x}^{*} \geq 0$.

It means that in the case when all factors of production were used, then terms are executed:

$\mathrm{w}-\lambda^{*} \mathrm{MP}\left(\mathrm{x}^{*}\right)=0$;

$\mathrm{q}=\mathrm{F}\left(\mathrm{x}^{*}\right)$.

Deciding the system of equalizations (17) at in-out parameters and $\left(x_{j}^{*}>0, j=1, \ldots, m\right)$, find the corresponding function of demand of firm on resources:

$\mathrm{x}^{*}=\xi(\mathrm{w}, \mathrm{q})$,

Function of charges of enterprise:

$\mathrm{C}(\mathrm{w}, \mathrm{q})=\mathrm{C}(\xi(\xi(\mathrm{q}))$,

But function of incomes of enterprise:

$\pi(\mathrm{w}, \mathrm{q})=\mathrm{pq}-\mathrm{C}(\xi(\xi(\mathrm{q}))$,

as functions of parameters and task in (13) [11],[12]. Comparing the obtained results for the task of minimization of charges of firm with the decision of neoclassical task of maximization of incomes of enterprise, see that in case of optimal suggestion for the last task of upshots of task of minimization of charges will satisfy correlation: 
$\mathrm{x}^{*}\left(\mathrm{w}, \mathrm{q}_{*}\right)=\xi\left(\mathrm{w}, \mathrm{q}_{*}\right) \mathrm{x}_{*}(\mathrm{w})$,

so that:

$\lambda^{*}\left(\mathrm{w}, \mathrm{q}_{*}\right)=\frac{\mathrm{w}_{\mathrm{j}}}{\mathrm{MP}_{\mathrm{j}}\left(\mathrm{x}_{*}\right)}=\mathrm{p}$.

Stopped for intercommunication of tasks of maximization of producing of products (4) and minimization of charges (13). Possibly, $\mathrm{x}^{*}(\mathrm{c}) \mathrm{i}^{*}=\mathrm{Q}(\mathrm{c})=\mathrm{F}\left(\mathrm{x}^{*}(\mathrm{c})\right)$ that price in these tasks is fixed and identical. Even if decision of task of maximization of producing of products (4) $x^{*}(q), C(q)=x^{*} q(w)$ and upshots of task of minimization of charges (13) $\mathrm{c}=\mathrm{C}(\mathrm{q})$, both at in a task (4) $\mathrm{q}^{*}=\mathrm{Q}(\mathrm{c})=\mathrm{q}$ have, if in a task (3.13) $\mathrm{C}(\mathrm{q})=\mathrm{c}$ [13],[14], [15].

\subsection{Estimation of Minimization of Charges}

For the decision of task the vehicle of theory of duality is used for the mathematical analysis of optimal plan of the concave programming. On the basis of the information resulted in table 1 , the task of the optimal use of resources decides on a maximum of profit yield from realization of the prepared products and minimization of charges.

Table 1. Initial data

\begin{tabular}{|c|c|c|c|c|c|c|}
\hline \multirow{2}{*}{$\begin{array}{l}\text { Type of } \\
\text { resources }\end{array}$} & \multicolumn{5}{|c|}{ Norms of charges are on unit of products } & \multirow{2}{*}{$\begin{array}{l}\text { Supplies of } \\
\text { resources }\end{array}$} \\
\hline & Truck beams & Tal is electric & $\begin{array}{l}\text { Reducing } \\
\text { Motor-gear }\end{array}$ & Telpher & Reducing gear & \\
\hline Labor & 5 & 8 & 7 & 7 & 4 & 3000 \\
\hline Raw material & 5 & 5 & 6 & 4 & 5 & 2800 \\
\hline Equipment & 5 & 5 & 6 & 5 & 6 & 3600 \\
\hline Cost of goods & 757 & 1465 & 985 & 2100 & 1210 & \\
\hline
\end{tabular}

By setting a direct optimization task on a maximum of profit yield from realization of the prepared products, to get the optimal plan of producing of products [16-22]

$\mathrm{X}_{1}$ - norm of charges of resources cranes;

$\mathrm{X}_{2}$ - norm of charges of resources electric;

$\mathrm{X}_{3}$ - norm of charges of resources electric reducing motorgear;

$\mathrm{X}_{4^{-}}$norm of charges of resources electric telpher;

$\mathrm{X}_{5}$ - norm of charges of resources electric reducing gear.

An objective function looks like:

$$
\begin{aligned}
& {\left[\begin{array}{l}
\mathrm{f}(\mathrm{x})=757 \mathrm{x}_{1}+1465 \mathrm{x}_{2}+985 \mathrm{x}_{3} \\
+2100 \mathrm{x}_{4}+1210 \mathrm{x}_{5} \rightarrow \max
\end{array}\right],} \\
& x_{1,2,3,4,5} \geq 0 .
\end{aligned}
$$

Limitations:

a) on labor:

$5 \mathrm{x}_{1}+8 \mathrm{x}_{2}+7 \mathrm{x}_{3}+7 \mathrm{x}_{4}+4 \mathrm{x}_{5} \leq 3000$

b) on raw material:

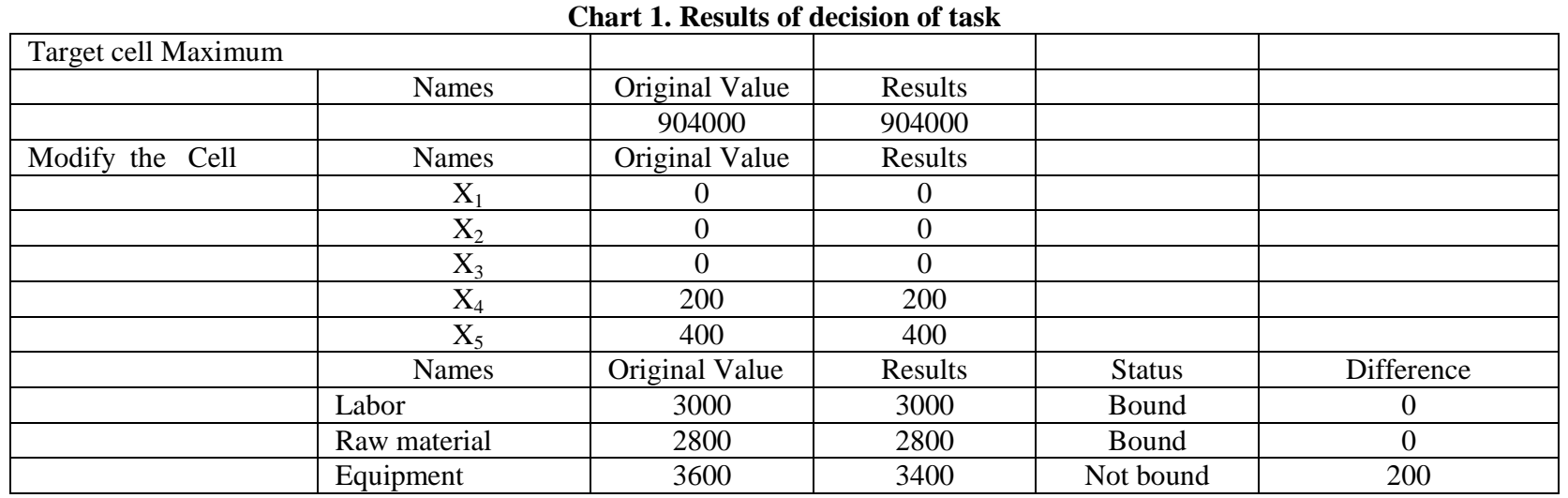

\begin{tabular}{|c|c|c|}
\hline \multicolumn{3}{|c|}{ Modify the cell } \\
\hline Names & $\begin{array}{l}\text { Results } \\
\text { Value }\end{array}$ & $\begin{array}{c}\text { Target } \\
\text { Coefficient }\end{array}$ \\
\hline $\mathrm{X}_{1}$ & 0 & 757 \\
\hline $\mathrm{X}_{2}$ & 0 & 1465 \\
\hline $\mathrm{X}_{3}$ & 0 & 985 \\
\hline $\mathrm{X}_{4}$ & 200 & 2100 \\
\hline
\end{tabular}

The decision of ambivalent task can be found by using mathematical analysis in chart 2 .

Chart 2. Results of decision of task

\begin{tabular}{|l|c|c|c|}
\hline \multicolumn{1}{|c|}{$\mathrm{X}_{5}$} & \multicolumn{2}{c|}{400} & 1210 \\
\hline Limitations & $\begin{array}{c}\text { Results } \\
\text { Value }\end{array}$ & $\begin{array}{c}\text { Shadow } \\
\text { Price }\end{array}$ & $\begin{array}{c}\text { Restrictions } \\
\text { Right side }\end{array}$ \\
\hline Labor & 3000 & 297.895 & 3000 \\
\hline Raw material & 2800 & 3.68421 & 2800 \\
\hline Equipment & 3600 & 0 & 3600 \\
\hline
\end{tabular}

In chart 1 , there is an optimal value of variables that accordingly equal $0,0,0,200,400$; value of objective function of 904000 , and also used insufficient resource in size of 200 units and got values of maximal profit yield from realization of the prepared products (904000 odes.) an enterprise can get 200 units of tempers and 400 units of reducing gears at producing. Thus resource «labor» and raw «material» will be used fully, and from 3600 units equipments will be used only 3400 units. By considering forth an ambivalent task and will find it optimal plan by means of theorem of duality [23], [24]. A result over is brought in chart-1.

$5 \mathrm{x}_{1}+5 \mathrm{x}_{2}+6 \mathrm{x}_{3}+4 \mathrm{x}_{4}+5 \mathrm{x}_{5} \leq 2800$

c) on an equipment:

$5 x_{1}+5 x_{2}+6 x_{3}+5 x_{4}+6 x_{5} \leq 3600$ (1) (n) . (n)

(1)


The number of unknown in an ambivalent task equals the number of functional limitations in an initial task [25],[26]. An initial task contains 3 limitations: labor, raw material and equipment. Thus, in an ambivalent task 3 unknown:

$\mathrm{y}_{1-}$ an ambivalent estimation of resource is labor;

$\mathrm{y}_{2}$ - ambivalent estimation of resource of raw material;

$\mathrm{y}_{3}$ - ambivalent estimation of resource of equipment.

The objective function of ambivalent task is formulated on a minimum. Coefficients at unknown in the objective function of ambivalent task are free members in the system of initial task:

$\mathrm{g}(\mathrm{y})=3000 \mathrm{y}_{1}+2800 \mathrm{y}_{2}+3600 \mathrm{y}_{3} \rightarrow \min$

The number of limitations in the system of ambivalent task equals the number of variables at an initial task [27]. In initial task 5 variables, thus, there are 5 limitations in an ambivalent task. In right parts of limitations of ambivalent task coefficients stand at unknown in the objective function of initial task. The left part determines the cost of type of raw material, spending on the production of unit of products. Every limitation meets the certain standard of charges of raw material on unit of products:

$$
\begin{array}{r}
5 y_{1}+5 y_{2}+5 y_{3} \geq 757 \\
8 y_{1}+5 y_{2}+5 y_{3} \geq 1465, \\
7 y_{1}+7 y_{2}+7 y_{3} \geq 985, \\
7 y_{1}+4 y_{2}+5 y_{3} \geq 2100 \\
4 y_{1}+5 y_{2}+6 y_{3} \geq 1210 \\
y_{1,2,3,4,5} \geq 0
\end{array}
$$

To find the optimal plan of ambivalent task, using the theorems of duality

$$
\mathrm{y}_{\mathrm{i}}\left(\sum_{\mathrm{j}=1}^{\mathrm{n}} \mathrm{a}_{\mathrm{ij}} \mathrm{x}_{\mathrm{j}}-\mathrm{b}_{\mathrm{i}}\right)=0 \text {, }
$$

Then:

$\mathrm{y}_{1}\left(5 \mathrm{x}_{1}+8 \mathrm{x}_{2}+7 \mathrm{x}_{3}+7 \mathrm{x}_{4}+4 \mathrm{x}_{5}-3000\right)=0$,

$\mathrm{y}_{2}\left(5 \mathrm{x}_{1}+5 \mathrm{x}_{2}+6 \mathrm{x}_{3}+4 \mathrm{x}_{4}+5 \mathrm{x}_{5}-2800\right)=0$,

$\mathrm{y}_{3}\left(5 \mathrm{x}_{1}+5 \mathrm{x}_{2}+6 \mathrm{x}_{3}+5 \mathrm{x}_{4}+6 \mathrm{x}_{5}-3600\right)=0$.

$\left(\mathrm{x}^{*}\right)=(0 ; 0 ; 0 ; 200 ; 400)$.

Then, put the optimal values of vector in the got expressions $\mathrm{y}_{1}(0+0+0+200 \times 7+400 \times 4-3000)=0$;

$\mathrm{y}_{2}(0+0+0+200 \times 4+400 \times 5-2800)=0$;

$\mathrm{y}_{3}(0+0+0+200 \times 5+400 \times 6-3600)=0$.

And will get:

$$
\begin{aligned}
& \mathrm{y}_{1}(3000-3000)=0 ; \\
& \mathrm{y}_{2}(2800-2800)=0 ; \\
& \mathrm{y}_{3}(3400-3600)=0, \text { so as }
\end{aligned}
$$

In a task, that is why fourth and fifth limitations grow into equality:

$$
\begin{gathered}
7 y_{1}+4 y_{2}+5 y_{3}=2100 \\
4 y_{1}+5 y_{2}+6 y_{3}=1210 ; \\
y_{3}=0
\end{gathered}
$$

Deciding the system of equalizations will get:

$\mathrm{y}_{1}=297.895, \mathrm{y}_{2}=3.68421, \mathrm{y}_{3}=0$.

By comparing implementation of the first theorem of duality:

$$
\begin{aligned}
\mathrm{g}(\overline{\mathrm{y}}) & =3000 \mathrm{y}_{1}+2800 \mathrm{y}_{2}+3600 \mathrm{y}_{3} \\
& =3000 \times 297.895+2800 \times 3.68421+3600 \times 0 \\
& =904000 \\
\mathrm{f}(\overline{\mathrm{x}}) & =757 \mathrm{x}_{1}+1465 \mathrm{x}_{2}+985 \mathrm{x}_{3}+2100 \mathrm{x}_{4}+1210 \mathrm{x}_{5} \\
= & 757 \times 0+1465 \times 0+985 \times 0+ \\
+ & 2100 \times 200+1210 \times 400=904000 .
\end{aligned}
$$

Then to explain zero values of variables in an optimal plan, put in limitation of ambivalent task the optimal value of vector:

$$
\begin{gathered}
5 \mathrm{y}_{1}+5 \mathrm{y}_{2}+5 \mathrm{y}_{3} \geq 757, \\
1489.48+18.42+0 \geq 757, \\
1507.9 \geq 757 \\
8 \mathrm{y}_{1}+5 \mathrm{y}_{2}+5 \mathrm{y}_{3} \geq 1465, \\
2383.16+18.42+0 \geq 1465, \\
2401.58 \geq 1465, \\
7 \mathrm{y}_{1}+7 \mathrm{y}_{2}+7 \mathrm{y}_{3} \geq 985, \\
2085.27+25.79+0 \geq 985, \\
2111.06 \geq 985 \\
7 \mathrm{y}_{1}+4 \mathrm{y}_{2}+5 \mathrm{y}_{3} \geq 2100, \\
2085.27+14.74+0 \geq 2100, \\
2100=2100, \\
4 \mathrm{y}_{1}+5 \mathrm{y}_{2}+6 \mathrm{y}_{3} \geq 1210, \\
1191.58+18.42+0 \geq 1210, \\
1210=1210 .
\end{gathered}
$$

Charges on cranes, tall are electric and a reducing motor-gear exceed a price. That is cost of norm of charges on unit of good more than cost of good. These wares will not enter an optimal plan from their un profitableness. To analyze the use of resources in the optimal plan of initial task:

$$
\begin{aligned}
& 3000 \leq 3000, \\
& 2800 \leq 2800, \\
& 3400 \leq 3600 .
\end{aligned}
$$

The supplies of raw material on the first and second kind were used fully, and on the third type of equipment of it were not used 200. To define, as a profit yield and plan of producing of products will change at the increase of supplies of raw material on 250 units. From a theorem about estimations it is known that oscillation of size results in an increase or reduction. It is determined:

$\Delta \mathrm{f}(\overline{\mathrm{X}})^{*}=\Delta \mathrm{b}_{\mathrm{i}} \mathrm{y}_{i}^{*}$,

$\Delta \mathrm{b}_{1}=250$,

$$
\begin{aligned}
& \Delta \mathrm{f}(\overline{\mathrm{X}})^{*}=\Delta \mathrm{b}_{1} \mathrm{y}_{1}^{*}=250 * 297.895=74473.7, \\
& \Delta \mathrm{f}(\overline{\mathrm{X}})_{\text {new }}^{*}=904000+74473.7=978473.7(\text { od. })
\end{aligned}
$$

From calculations evidently, if we will increase the supplies of raw material on 250 units, then earnings will increase on 74773,7 units, therefore a general profit yield will make 978473,7 units after the change of supplies. Thus the structure of plan did not change wares that were to the loss did not enter the new plan of producing, so however prices did not change on them [28], [29],[30].

$$
\begin{array}{r}
5 x_{1}+8 x_{2}+7 x_{3}+7 x_{4}+4 x_{5} \leq 3000 \\
5 x_{1}+5 x_{2}+6 x_{3}+4 x_{4}+5 x_{5} \leq 2800 \\
5 x_{1}+5 x_{2}+6 x_{3}+5 x_{4}+6 x_{5} \leq 3600
\end{array}
$$

To decide the system of equalizations and will get: 


$$
\mathrm{x}_{4}=265.789, \mathrm{x}_{5}=347.368 .
$$

For new optimal plan, Change of total worth of products on 74473.7 units it is not due to the increase of plan of producing of tempers on 65.789 at price 2100 units:

$(2100 \times(265.789-200))=38156.9$ (odes. $)$.

And reduction on 52.6316 units of the plan producing of reducing gears at price 1210 units:

$(1210 \times(347.368-400))=-63684.236($ od. $)$.

Automation of development was carried out on the basis of the algorithm presented in chart 3 and results of traditional method are given in chart 4 .

\section{COMPARISON}

The development allows carrying out the plan of production on the basis of optimization of correlation of charges, profits and income, as a result of what possibility to determine the volumes of output and price at that appears there will be a maximal profit yield from realization and minimum charges. To advantages of development it is possible to take:

- possibility of application in other economic structures of industrial industry :

- possibility instantly to obtain information about the sums of charges and income at the change of weekend of data (for example, at a price, volumes of output change and others like that);

- comfortable use that consists of speed of calculation, him small labor intensiveness

- possibility of receipt of data is for an economic analysis.

For determination of competitiveness it is necessary to compare development to the analogue after the row of properties and date estimation them. In quality to the analogue it is suggested to detect a method is traditionally accepted, when calculations of profit yield are from realization, on raw material it is executed the plan of producing of products and prices by hand. The choice of properties depends on that from them is most essential for an enterprise. To such properties it is possible to take:

- charges of time are on realization of operations for planning of charges and producing;

- financial consequences of making decision.

To estimate, what results on the indicated parameters give two comparative methods of management charges. Comparing over of charges of time to the traditional analogue is brought in a table 2 .

Table 2. Comparison of development and to the analogue for to the monthly charges of time on an operation for planning of charges and producing

\begin{tabular}{|c|c|c|c|c|c|}
\hline \multirow[t]{2}{*}{ No. } & \multirow[t]{2}{*}{ Type of work } & \multicolumn{2}{|c|}{ Charges of time, by hours } & \multirow{2}{*}{$\begin{array}{l}\text { Economy of } \\
\text { time }\end{array}$} & \multirow[t]{2}{*}{ Sources of economy } \\
\hline & & developments & $\begin{array}{l}\text { to the } \\
\text { analogue }\end{array}$ & & \\
\hline 1 & $\begin{array}{l}\text { Collection of information } \\
\text { is from a production }\end{array}$ & 1.0 & 3.0 & 2.0 & $\begin{array}{l}\text { Computer input and storage } \\
\text { of past data }\end{array}$ \\
\hline 2 & $\begin{array}{l}\text { Creation of data is in a } \\
\text { table form }\end{array}$ & 0.5 & 3.0 & 2.5 & $\begin{array}{l}\text { Work with the package of } \\
\text { Mathematical calculations }\end{array}$ \\
\hline 3 & $\begin{array}{l}\text { Procedure of calculation of } \\
\text { model parameters }\end{array}$ & 0.1 & 2.0 & 1.9 & Automation \\
\hline 4 & $\begin{array}{l}\text { A concordance of results is } \\
\text { with a business manager }\end{array}$ & 0.3 & 0.3 & - & \\
\hline & All & 2.8 & 8.3 & 5.5 & \\
\hline
\end{tabular}

For comparison after the financial consequences of making decision it is necessary to execute calculations: what profit yield from realization and price on raw material is given by the offered model and what traditional method. As evidently from these tables of price on raw material less than at application of model of this works. A profit yield from realization in obedience to the offered model makes 904000 uah.s, that on 44330 hrn.s more than profit yield that it is expected by a traditional method. In an order to estimate the competitiveness of the offered development, parameters that were squashed are needed, to erect internals in an only summarizing index. Therefore estimation on every parameter must be self-weighted on his importance.

Chart 3. Results of calculations by means of the offered model in this work

\begin{tabular}{|l|c|c|c|}
\hline \multicolumn{4}{|c|}{ Target Cell Maximum } \\
\hline & Names & Results & \\
\hline & & 904000 & \\
\hline & & & \\
\hline \multicolumn{4}{|c|}{ Modify Cell } \\
\hline & Names & Results & \\
\hline
\end{tabular}

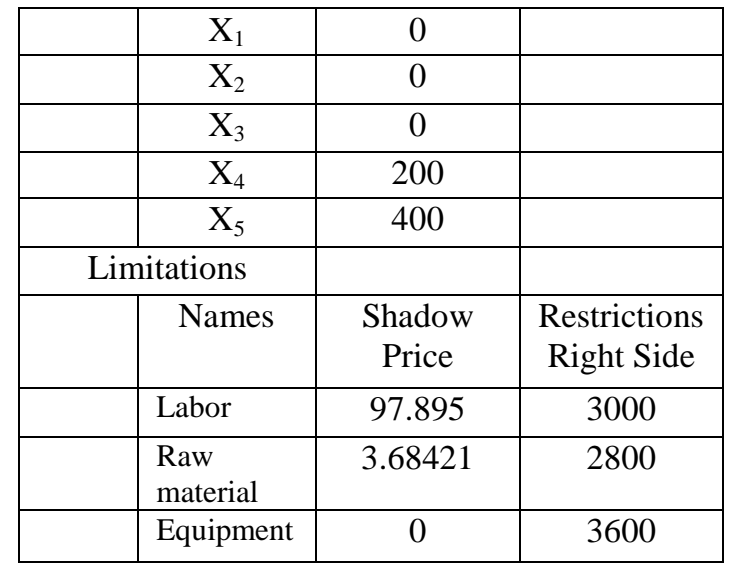

Chart 4. Results of calculations of traditional method

\begin{tabular}{|l|c|c|c|}
\hline \multicolumn{3}{|c|}{ Target Cell (Maximum) } & \\
\hline & Names & Results & \\
\hline & & 859670 & \\
\hline & & & \\
\hline \multicolumn{3}{|c|}{ Modify Cell } & \\
\hline
\end{tabular}




\begin{tabular}{|c|c|c|}
\hline Names & Results & \\
\hline $\mathrm{X}_{1}$ & 0 & \\
\hline $\mathrm{X}_{2}$ & 0 & \\
\hline $\mathrm{X}_{3}$ & 0 & \\
\hline $\mathrm{X}_{4}$ & 200 & \\
\hline $\mathrm{X}_{5}$ & 400 & \\
\hline \multicolumn{3}{|l|}{ Limitations } \\
\hline Names & $\begin{array}{l}\text { Shadow } \\
\text { Price }\end{array}$ & $\begin{array}{l}\text { Restrictions } \\
\text { Right Side }\end{array}$ \\
\hline Labor & 337.815 & 3000 \\
\hline Raw material & 7.74372 & 2800 \\
\hline Equipment & 0 & 3600 \\
\hline
\end{tabular}

Main task is that, put at developments of model minimization of charges of enterprise and here to be not at a loss. It is possible to consider the increase of profit yield the basic result of the use of this model from realization. Greater importance of a 0,7 point is Therefore appropriated this index. Other a 0 , 3 point were taken on the charges of time of managing labor. A calculation over of summarizing index of quality of development comparatively with a traditional analogue is brought in a table 3 .

Table 3. Calculation of summarizing index of quality of development comparatively with a traditional analogue

\begin{tabular}{|c|c|c|c|c|c|c|}
\hline Parameters & $\begin{array}{c}\text { Odes. } \\
\text { Unit. }\end{array}$ & Model & $\begin{array}{c}\text { Traditional } \\
\text { analog }\end{array}$ & $\begin{array}{c}\text { Weight to the } \\
\text { pair meter of di }\end{array}$ & $\begin{array}{c}\text { Single index } \\
\text { of qi }\end{array}$ & $\begin{array}{c}\text { Erected } \\
\text { index } \\
\text { di x qi }\end{array}$ \\
\hline $\begin{array}{c}\text { A profit yield is } \\
\text { from realization }\end{array}$ & $\begin{array}{c}\text { thousand } \\
\text { uah }\end{array}$ & 904.0 & 859.7 & 0.7 & 1.052 & 0.74 \\
\hline $\begin{array}{c}\text { Charges of time are } \\
\text { on a management }\end{array}$ & by hours & 2.8 & 8.3 & 0.3 & 2.96 & 0.89 \\
\hline \multicolumn{7}{|c|}{ All } \\
\hline
\end{tabular}

As a calculation showed, the offered model of minimization of charges gets along at the put tasks in 1, 63 times better than the method used in practice. A calculation needs to be begun with the calculation of labor intensiveness of implementation of works and over of labor of works is brought in a Table 4 .

Table 4. Calculation of labor on creation of model of charges

\begin{tabular}{|l|c|}
\hline Types of work & Amount per-days \\
\hline 1.Raising of task & 3 \\
\hline $\begin{array}{l}\text { 2.Development of } \\
\text { mathematical model }\end{array}$ & 5 \\
\hline $\begin{array}{l}\text { 3. Development of algorithm } \\
\text { of decision of task }\end{array}$ & 4 \\
\hline $\begin{array}{l}\text { 4.Automation mathematical } \\
\text { calculation }\end{array}$ & 4 \\
\hline 5.Registration of documentation & 2 \\
\hline All labor & 18 \\
\hline
\end{tabular}

Now, it is possible to calculate charges on the remuneration of labor of workers that take part in product development. A wage-fund is determined after a formula:

$\mathrm{Wgs}=\mathrm{S}_{\mathrm{days}} * \mathrm{Tn}$,

Where, Wgs - the daily earnings of model developer, expected on the basis of monthly salary (in size of a 800 uah.) and number of working days in a month (24 working days), : Wgs $=800 / 24=33.3$ (uah./of days),

$\mathrm{T}$ - labor for product development, according to a Table-3 $\mathrm{T}=18$ days. Withholdings expect on social security, when developers work after the ordinary system of taxation. All, extra charges on a wage-fund fold $37.2 \%$ and settles accounts after a formula:

OCC $=0.372$ wgs,

where, OCC - contribution on social security

OCC $=0.372 \times 799.5=295.8$ (uah. .
The cost of (little value and quickly objects) is determined by an empiric way:

$\mathrm{Vq}=$ diskette + of 0.1 bundles of paper $+\mathrm{a} 1$ pen

$=3$ uah.s +1.6 uah.s $+\mathrm{a} 1$ uah $==5.6$ (uah.).

The use of computers brings to three groups over of charges. Firstly, depreciation of computer technique, secondly, depreciation of software, thirdly, charges on electric power. Depreciation of computer technique it is better to determine a rectilinearly method. This method answers the aims of this calculation of to define by the best character, what part of computer cost must be carried on the cost of development, going out the terms of exploitation:

$$
\mathrm{AO}_{\mathrm{kT}}=\frac{\mathrm{C}_{\mathrm{KT}}}{\mathrm{t}_{\text {expt }}} \times \mathrm{M},
$$

Where, AO - a sum of depreciation of computer equipment, including the cost of development

Скт - initial cost of computer technique,

Скт $=2000$ uah.s,

$\mathbf{t}_{\text {'expt }}$ - term of exploitation of computer technique in working days, $2=2 \times 12 \times 24=576$ days

M- expense of machine time, coming from a table- 3 from all charges of time of the use of computer it is needed at development of algorithm of decision of task, automation of calculation by means of Mathematically, all $\mathrm{M}=10$ days.

$$
\mathrm{AO}_{\text {кт }}=\frac{2000}{576} \times 25=86.8 \text { uah } \text {. }
$$

Depreciation of software is determined by an analogical method. The cost of the licensed software product of Microsoft Office in middle makes 600 uah, term of exploitation of -1 , therefore 288 working days.

$$
\mathrm{AO}_{\text {по }}=\frac{600}{288} \times 10=20.8 \text { (uah.). }
$$

Charges on electric power: 
$\mathrm{E}=\mathrm{Mkt} \times(\operatorname{Mo} \times$ of $7 \mathrm{yr}$.$) ,$

where, $\mathrm{E}$ - charges on electric power, that join in the cost of development. MKT - power of computer technique, amount of electric power, that is consumed at o'clock, MKT $=0.2$ $\mathrm{kW} /$ year. That tariff for the use of electric power, that $=0.195$ uah.s $/ \mathrm{kW} . \mathrm{E}=0.2 \times(10 \times 7) \times 0.195=2.7 \mathrm{uah}$

General running charges include rent for an apartment, salary of administration, paying for services of connection, cleaning of, illumination and others like that. In this case to determine a direct account general running charges beside the purpose. It is constrained, firstly, with that they belong not only on the worked out product, secondly, their fate very had comparatively with other charges. Will accept general running charges in size of $3 \%$ from the sum of all above enumerated charges for development

The use of model of charges requires from an enterprise nevertheless fluid charges:

- salary of specialists, using a model, with extra charges;

- depreciation of computer equipment and software.

The salary of specialists is determined after a formula (3.28) taking into account extra charges. The salary of worker, carrying out planning of charges and producing, makes 2000 uah.s Thus, him a hours rate equals:

$$
\mathrm{S}_{\text {time }}=\frac{2000}{24 \times 7}=12 \text { (uah./year). }
$$

The final calculation of charges for development of model is executed as a Table 5 .

Table 5. Calculation of charges for development of model

\begin{tabular}{|l|c|c|}
\hline \multicolumn{1}{|c|}{ Types of charges } & Denotation & Total,uah \\
\hline \hline \multicolumn{1}{|c|}{ Wage-fund } & PTH & 799.5 \\
\hline A contribution is on social security & OCC & 295.8 \\
\hline $\begin{array}{l}\text { Cost of little value and quickly } \\
\text { wear out objects }\end{array}$ & IBE & 5.6 \\
\hline $\begin{array}{l}\text { Depreciation decrees are on a } \\
\text { computer technique }\end{array}$ & AOCT & 86.8 \\
\hline $\begin{array}{l}\text { Depreciation decrees are on } \\
\text { software }\end{array}$ & ADS & 20.8 \\
\hline Charges are on electricity & E & 2.7 \\
\hline General running charges & GR & 36.4 \\
\hline \hline All the charges for development & S & 1248.6 \\
\hline \hline
\end{tabular}

In general case a planning process taking into account automation will occupy 2.8 hours. But from these practically three hours on the use of the offered model will spend 6 minutes ( 0.1 hours), other charges are and at ordinary matterposition. Thus, charges on the remuneration of labor of workers will lay down:

$\mathrm{PS}_{\exp }=12 \times 0.1 \times 1.37=1.6$ ( uah./of miss).

Depreciation of computer technique and software will define after a formula (31):

$$
\mathrm{AO}_{\text {кт }}=\frac{2000}{576 \times 7} \times 0.1=0.05 \text { (uah./of month). }
$$

As running expenses are not comparably small with the order of other charges, will accept them even 0 . An economic effect from introduction of development will appear in two directions:

- reduction of charges to time is on an operation on a management charges;

- an increase of profit yield is from realization of enterprise.
Calculation of economic effect from the economy of labor force after a formula (33):

Emonth $=(\mathrm{So}-\mathrm{Si}) \times \mathrm{Syr}$,

where, Emonth - monthly effect from introduction of development; So- base charges of time on an operation on assembling of plan; in obedience to a Table-1 Salary $=8.3$ hours; Again new charges of time on an operation on assembling of plan after introduction of development; in obedience to a Table- 1 Wages $=2.8$ hours; Salary in a year of sentinel pay of specialists carrying out planning of Salary a year $=12$ uah.s/by hours rate. Thus, an economic effect from the economy of labor at introduction of development will lay down

$$
\text { Emonth }=(8.3-2.8) \times 12=66 \text { (uah./of miss). }
$$

An economic effect from the increase of profit yield from realization is expected coming from equations (4) and (5).

$$
\begin{aligned}
\mathrm{EB} & =\mathrm{B} \text { Models analogue }=904000-859670 \\
& =44330 \text { uah.s }
\end{aligned}
$$

Thus a profit yield from realization was mega scope on 44330grn.s. Will expect such indexes of economic efficiency:

- annual effect of efficiency;

- term of recoupment.

An annual economic effect is determined as an economy of charges for a year. It is determined as a sum of monthly effect, got on a draught 12 months:

Eyr $=$ Emonths $\times 12$ months. $=66 * 12=792$ uah.s

The term of recoupment in default of running expenses settles accounts after a formula (36):

$$
\mathrm{T}_{\mathrm{TR}}=\frac{\mathrm{R}}{\mathrm{E}_{\text {month }}} \text {, }
$$

Where, TR - term of recoupment,

$\mathrm{R}$ - of expense for development of model (Table-4), $\mathrm{R}=1248.6$ uah

$$
\mathrm{T}_{\mathrm{TR}}=\frac{1248.6}{66}=19 \text { months. }
$$

Thus, charges for development and use of model of in the second year of the use. An economic effect on the second parameter can be defined, counting on how many megascopic profit yields from realization of enterprise:

$$
\Delta \mathrm{E}=\frac{904000-859670}{859670}=0.05 .
$$

As a result of introduction of the offered calculations there was an increase of profit yield from realization on $5 \%$.

\section{CONCLUTION}

This research article intends a method that describes the exquisite plan of production, which is determined on a maximum of profit yield and minimum charges. Defined the optimal plan of producing of products with a maximum of profit yield and found such prices on the types of raw material, that charges were minimized. And also explained zero values in an optimal plan and defined, as a profit yield and plan of producing of products will change at the increase of supplies of raw material. The theoretical aspects of management charges are analyzed and comparative description over of classification of charges are brought. Thus, it is possible to draw conclusions, that minimization of 
charges is the major index of the efficiency of economic activity of expensive enterprise.

\section{ACKNOWLEDGEMENT}

Our thanks for the experts who have contributed towards the development of this work.

\section{REFERENCES}

[1] Charges of enterprise: Teach. Manual. - Kyiv: TSUL, 2002. - 656 p.s.

[2] AN Asaul Office of the average by expenses on the company: methodical of Allowance. - of St. Petersburg., 1995.

[3] Asaul AN, Kudryavtsev AV, fish EI, AF Klyuev Economics of entrepreneurship: learning. Allowance. Of Moscow: Izd ACB, Ed.: SPbHASU, 2000.

[4] Dolzhenkova VR cost of production: formation and analysis: learning. Allowance. - Of Novosibirsk: Novosyb. state. Acad. Economy and Control, 1998.

[5] Lebedev VG, Drozdova TG, Kustarev VP, Asaul AN Osoreva IB By expenses on the Management of the enterprise: Textbook / Ed editor of Doctor X. district. Sci. GA Krajukhina. - Of St. Petersburg.: Yzd.dom of Business-Press, 2000. 277 p.s.

[6] Lebedev VG, Drozdova TG, Kustarev VP, Asaul AN Osoreva IB By expenses on the Management of the enterprise: Textbook / ed editor of Doctor X. district. Sci. GA Krajukhina. - Of St. Petersburg.: Yzd.dom of «Business-Press, 2003. 256 p.s.

[7] EA Molchalyna System by management expenses: Textbook. Allowance. - Of Irkutsk, 1997.

[8] The economy of enterprises. VJ Horfynkelya, VA Shvandara. - 2th ed. Moscow. - 1998. 247 p.s.

[9] Menshikov SM Novaya economy. Fundamentals of with economic known. The manual of Allowance. - Moscow: International relations of 1999.400 p.s.

[10] Economy of enterprise. Textbook. For common. Ed. SF Pokropyvnoho. - Of K.: MBK, 2000. - 528 p.s.

[11] Abryutina MS, Grachev AV Analysis of Finance and the economic activities of enterprises: the schoolprakycheskoe of Allowance. - Of Moscow: Izd "of Delhi and of Service", 1998. - 256 p.s.

[12] Analysis of benefits and charges: RUF. a manual / is Secretariat of Advice of Skrabnytsi of Canada; Trudged. from the eng of - of K.: Bases 1999. - 175 p.s.

[13] Andreychykov AV Andreychykova O. Analysis, synthesis, planning of solutions in economy. - Of Moscow: Finance and of statistician, 2000. - 368 p.s.
[14] Bakanov M. I., AD Sheremet Theory of economic analysis: Textbook. - 4th edition., Ext. and pererab. - Of Moscow: Finance and of statistician, 2002. - 416 p.s

[15] E. L. Basovskyy Theory of economic analysis: Manual of Allowance. - Of Moscow: Infra-M, 2001. - 222 p.

[16] Robert H. Frank Microeconomics and behavior: McGraw-Hill, 1991.

[17] Mas-Collel A., Whinston M.D., Green J.R. Microeconomic Theory. - New York: Oxford Univ. Press, 1995.

[18] Karahodova OO, Chervanyov DM Microeconomics. K.: The Fourth Wave, 1997.

[19] Yastremska OI, OG Gryshchenko Principles of Microeconomics. - K.: T-"Knowledge", cp, 1993.

[20] Ponomarenko O.I. Modern Microeconomic Analysis. Intensive Course. - Kyiv: Kyiv Univ., 2000.

[21] Varian H.R. Microeconomic Analysis. - 3rd ed. - New York; London: Norton, 1992.

[22] Modern Economic Analysis: In Part 12 hours. Microeconomics: Teach. Manual. / OI Ponomarenko, NA Perestyuk, VM Brown. - K.: High school., 2004. - 262 sec.: Ill.

[23] Handbook of Mathematical Economics / K.J. Arrow, M.D. Intrilligator (eds.).- Amsterdam: North - Holland, 1981. - Vol.1-2, 1983. - Vol. 3.

[24] L. Kantranovych Mathematical methods for planning the organization and productions .-L.,1999.

[25] AI Ponomarenko, Ponomarenko VA System methods in economics, management and business. - K.: Lybid, 1995.

[26] Takayama A. Analytical Methods in Economics. - New York: harvester wheat Sheaf, 1994.

[27] Varian H.R. (Ed.). Computational Economics and Finance. Modeling and Analysis with Mathematical. New York: Springer-Verlag, Inc., 1996.

[28] Wijaard J. Beyond MRP-2: On the future of Standard Software for Production Planning and control / / Logistics in Remote Locations: A Case Study / Logistics Inform / Manag.V.3,№ 4, 1990.

[29] Modern methods of production organization. Razd.2. Materyalnoe hoz-in, Logistics and Inform. Management /method. Arriving Sov.-Germ. Zin.-RUF. seminar. L., 1991.

[30] N. Ivanova Production break-even analysis: Theory and Practice: Training Manual. - Kyiv: Libra, 2002. - 72 sec. 